Article

\title{
Corrosion of MgO-C with Magnesium Aluminate Spinel Addition in A Steel Casting Simulator
}

\author{
Steffen Dudczig ${ }^{1}$, Gert Schmidt ${ }^{1}$, Christos G. Aneziris ${ }^{1}$, Christoph Wöhrmeyer ${ }^{2}$, \\ Christopher Parr ${ }^{2}$ and Patrick Gehre $1, *$ (D) \\ 1 Institute of Ceramic, Glass and Construction Materials, Technical University Bergakademie Freiberg, \\ Agricolastraße 17, 09599 Freiberg, Germany; steffen.dudczig@ikgb.tu-freiberg.de (S.D.); \\ gert.schmidt@ikgb.tu-freiberg.de (G.S.); christos.aneziris@ikgb.tu-freiberg.de (C.G.A.) \\ 2 Imerys Aluminates, Immeuble Pacific, 11, cours Valmy, Paris La Défense, 92800 Puteaux, France; \\ christoph.wohrmeyer@imerys.com (C.W.); chris.parr@imerys.com (C.P.) \\ * Correspondence: patrick.gehre@ikgb.tu-freiberg.de; Tel.: +49-3731-39-2709
}

Received: 11 November 2019; Accepted: 3 January 2020; Published: 9 January 2020

\begin{abstract}
For more than 20 years, the sidewalls and bottom of steel ladles have been lined with carbon-bonded magnesia (MgO-C) and magnesia-alumina bricks (MAC). The alumina raw materials react with magnesia forming a spinel, which decreases open porosity and slag infiltration. The amount, grain size, and chemistry of the added spinel impact the properties of spinel-containing MgO-C. Corrosion tests have been performed in a steel casting simulator at $1580^{\circ} \mathrm{C}$ using $18 \mathrm{CrNiMo} 7-6$ steel and Fe-rich slag as corrosion medium. Digital light microscopy and SEM/ EDS (scanning electron microscope with energy dispersive spectroscopy) were used to evaluate the corrosion mechanisms. The metal casting simulator test showed that the addition of $\mathrm{CaO}-\mathrm{MgO}-\mathrm{Al}_{2} \mathrm{O}_{3}$ aggregates results in the highest corrosion resistance against molten steel and synthetic basic slag compared to alumina-rich spinel aggregates.
\end{abstract}

Keywords: refractory ceramics; lifetime; corrosion

\section{Introduction}

$\mathrm{MgO}-\mathrm{C}$ exhibits excellent slag penetration resistance due to the non-wetting property of carbon. The combination of this good corrosion resistance with the high thermal shock resistance, low thermal expansion, high thermal conductivity, and high toughness makes it a superior refractory material for the slag line of steel ladles [1]. But poor high-temperature strength and the oxidation of carbon at operation temperature limit the service life of $\mathrm{MgO}-\mathrm{C}$ refractories. Lee and Zhang summarized the corrosion mechanisms of MgO-C [2]. The first decomposition step is the oxidization of the carbon component by surrounding oxygen and/or $\mathrm{FeO}$ (from the slag). Consequently, slag penetration and dissolution of the $\mathrm{MgO}$ grain proceed. Also, the reduction of $\mathrm{MgO}$ by carbon takes place at high temperatures. However, the subsequent reaction of $\mathrm{Mg}_{(\mathrm{g})}$ with oxygen, which leads to the formation of a dense secondary $\mathrm{MgO}-$ layer at the slag-refractory interface, will hinder slag penetration in turn. Additionally, the $\mathrm{CO}$ gas formed by carbon oxidation creates an excess pressure at the slag-refractory interface, which will hamper corrosion as well. The need of refractories with enhanced thermomechanical properties by steel producers led to the development of carbon-containing spinel-forming or spinel-containing bricks of type $\mathrm{Al}_{2} \mathrm{O}_{3}-\mathrm{MgAl}_{2} \mathrm{O}_{4}-\mathrm{C}$ [3]. Compared to conventional high alumina and doloma refractories, $\mathrm{Al}_{2} \mathrm{O}_{3}-\mathrm{MgAl}_{2} \mathrm{O}_{4}-\mathrm{C}$ bricks show better performance in steel ladle [4]. $\mathrm{Al}_{2} \mathrm{O}_{3}$ containing $\mathrm{MgO}-\mathrm{C}$ (AMC-bricks), where periclase and alumina form spinel $\left(\mathrm{MgAl}_{2} \mathrm{O}_{4}\right)$, exhibit excellent properties like high thermal shock and corrosion resistance as well as high thermal conductivity [5]. Similar to $\mathrm{Al}_{2} \mathrm{O}_{3}-\mathrm{MgAl}_{2} \mathrm{O}_{4}-\mathrm{C}$, the improved performance of AMC ladle bricks compared to conventional high 
alumina and doloma refractories have been proven [4]. Spinel contributes with its high refractoriness, high resistance to slag penetration and corrosion, and high thermal shock resistance [6]. In MgO-C, slag penetration decreases with increasing alumina content due to (a) spinel formation, (b) formation of aluminum nitride phases and aluminum carbide $\left(\mathrm{Al}_{4} \mathrm{C}_{3}\right)$, which reduce oxidation of carbon, and (c) an increase of slag viscosity by reaction of $\mathrm{Al}_{2} \mathrm{O}_{3}$ with slag compounds like $\mathrm{SiO}_{2}$ and $\mathrm{CaO}$ [7]. The addition of pre-reacted spinel (instead of $\mathrm{Al}_{2} \mathrm{O}_{3}$ ) to $\mathrm{MgO}-\mathrm{C}$ led to the development of $\mathrm{MgO}-\mathrm{MgAl}{ }_{2} \mathrm{O}_{4}-\mathrm{C}$ bricks, a new type of carbon-bonded spinel-containing refractories. Thereby, the material composition (spinel and carbon content) and the manufacturing process influence the properties of $\mathrm{MgO}-\mathrm{MgAl}_{2} \mathrm{O}_{4}-\mathrm{C}$ refractories. Choi and Jun presented a way of producing $\mathrm{MgO}-\mathrm{C}-\mathrm{MgAl}_{2} \mathrm{O}_{4}$ by adding thermite reaction products of $\mathrm{MgO}$ and $\mathrm{Al}$ to $\mathrm{MgO}-\mathrm{C}$ leading to superior corrosion resistance against $\mathrm{CaO} / \mathrm{SiO}_{2}$ slag (ratio 3.3) to $\mathrm{MgO}-\mathrm{C}$ and $\mathrm{MgO}-\mathrm{C}-\mathrm{Al}$ [8]. Ultra-low-carbon-containing $\mathrm{MgO}-\mathrm{MgAl}_{2} \mathrm{O}_{4}-\mathrm{C}$ bricks $(\mathrm{C}<1$ wt.\%) exhibit improved oxidation resistance, volume stability, $\mathrm{HMOR}$, and slag resistance. By applying these bricks in the slag line of a $200 \mathrm{t}$ converter, an average service life of 75 heats could be obtained [9]. Ganesh et al. demonstrated that $20 \mathrm{wt} . \%$ of spinel addition improves the slag erosion resistance of $\mathrm{MgO}-\mathrm{C}$ by $48 \%$ when the $\mathrm{MgAl}_{2} \mathrm{O}_{4}$ was prepared by reaction of a stoichiometric mixture of caustic $\mathrm{MgO}$ (particle size of $5 \mu \mathrm{m}$ ) with $\mathrm{Al}(\mathrm{OH})_{3}$ (particle size of $85 \mu \mathrm{m}$ ) [10]. Compared to MgO-C with commercially available micron-sized spinel, the addition of 0.5 and $1 \mathrm{wt} . \%$ nano-sized $\mathrm{MgAl}_{2} \mathrm{O}_{4}$ spinel prepared by citrate-nitrate gel method leads to improved resistance against oxidation, thermal spalling, and corrosion [11]. Nano-spinel affects the pore size distribution and hence limits the transportation of oxygen and slag into the matrix. This will protect graphite from being decarburized. Also, the chemistry of the spinel raw material impacts the properties of $\mathrm{MgO}-\mathrm{C}$. Wu et al. found that $\mathrm{CaAl}_{4} \mathrm{O}_{7}-\mathrm{MgAl}_{2} \mathrm{O}_{4}$ improves the thermal shock resistance of a MgO-C brick ( $4 \mathrm{wt} . \% \mathrm{C}$ ) and recommended the addition of $6 \mathrm{wt.} \%$ [12]. However, the differences in physical, mechanical, and thermomechanical properties of $\mathrm{MgO}-\mathrm{MgAl}_{2} \mathrm{O}_{4}-\mathrm{C}$ with various spinel raw materials have been found to be only marginal [13-15].

Fundamental investigations of the corrosion mechanism of $\mathrm{MgO}-\mathrm{MgAl}_{2} \mathrm{O}_{4}-\mathrm{C}$ refractories for application in steel ladles are not available so far. For the properties of $\mathrm{MgO}-\mathrm{MgAl}_{2} \mathrm{O}_{4}-\mathrm{C}$ refractories, the chemical composition of the spinel raw material is essential. Hence, the aim of this paper is to describe the influence of two common coarse-grained spinel raw materials on the corrosion mechanism of MgO-C. Laboratory corrosion test with molten steel and a basic synthetic ladle slag at $1580{ }^{\circ} \mathrm{C}$ under fully controlled conditions has been performed. The corrosion resistance and slag penetration were evaluated by analyzing the slag-refractory interface at macroscopic as well as microscopic scales in SEM.

\section{Materials and Methods}

As reference material, $\mathrm{MgO}$ with a maximum grain size of $4 \mathrm{~mm}$ and approx. $3 \mathrm{wt}$. $\%$ carbon content was produced (sample $\mathrm{MgO}-\mathrm{C}$ ). As carbon sources, carbon black and graphite were added in equal parts. CMA 72 clinker (Imerys Aluminates, Paris La Defense, France) and alumina-rich spinel AR78 with fraction 1-3 mm (Almatis GmbH, Frankfurt, Germany) serve as spinel raw material, respectively (mineral composition listed in Table 1). They were sieved to a grain size below $2 \mathrm{~mm}$ and replaced parts of the $\mathrm{MgO} 1-2 \mathrm{~mm}$ fraction. Additionally, $1.5 \mathrm{wt} . \%$ liquid and $1.5 \mathrm{wt} . \%$ powder resin and $0.3 \mathrm{wt} . \%$ hardener (hexamethylenetetramine) were added. The composition of the sample bodies can be found in Table 2.

Table 1. Mineral composition of fine-grained AR78 (-90 $\mu \mathrm{m})$ and CMA 72 (cement).

\begin{tabular}{|c|c|c|}
\hline Phase (wt.\%) & AR78 & CMA 72 \\
\hline $\mathrm{CaO} \cdot \mathrm{Al}_{2} \mathrm{O}_{3}$ & - & $18-22$ \\
\hline $\mathrm{CaO} \cdot 2 \mathrm{Al}_{2} \mathrm{O}_{3}$ & - & $8-12$ \\
\hline $\mathrm{MgAl}_{2} \mathrm{O}_{4}$ & 100 & $68-72$ \\
\hline $\mathrm{Ca}_{2} \mathrm{Al}\left[\mathrm{AlSiO}_{7}\right]$ & - & $<1$ \\
\hline
\end{tabular}


Table 2. Sample composition.

\begin{tabular}{cccc}
\hline Raw Material (wt.\%) & MgO-C & M-AR-C & M-CMA-C \\
\hline MgO & 97.8 & 92.8 & 92.8 \\
AR78 1-2 mm & - & 5.0 & - \\
CMA 72 clinker & - & - & 5.0 \\
Graphite “NFL" & 1.1 & 1.1 & 1.1 \\
Carbon black "N991" & 1.1 & 1.1 & 1.1 \\
Powder resin “0235 DP" & 1.5 & 1.5 & 1.5 \\
Liquid resin “9308-FL" & 1.5 & 1.5 & 1.5 \\
Hexamethylenetetramine & 0.3 & 0.3 & 0.3 \\
\hline
\end{tabular}

In a first step, the spinel raw materials were mixed with the coarse $\mathrm{MgO}$ fractions for $3 \mathrm{~min}$. Afterwards, tempered $\left(70{ }^{\circ} \mathrm{C}\right)$ liquid resin was added and mixed for another $2 \mathrm{~min}$ to coat the coarse grains. Finally, the fine components (residual $\mathrm{MgO}$, graphite, carbon black, powder resin, and hardener) were added followed by another 5 min mixing step. Afterwards, bar-shaped sample bodies with a dimension of $25 \times 25 \times 150 \mathrm{~mm}^{3}$ were prepared using a uniaxial press (RUCKS engine building $\mathrm{GmbH}$, Glauchau, Germany) and applied pressure of $120 \mathrm{MPa}$. After pressing, the samples were hardened by applying a three-step schedule up to a maximum temperature of $180^{\circ} \mathrm{C}$. The sample bodies were placed in a box filled with petrol coke and hence, thermal treatment (carbonization) was applied for 5 $\mathrm{h}$ at $1400{ }^{\circ} \mathrm{C}$ in a reducing atmosphere. After carbonization, the residual carbon content of $3 \mathrm{wt} . \%$ was calculated resulting from carbon black and graphite content, and the carbon yield of the resin binders.

$\mathrm{X}$-ray diffraction $(\mathrm{XRD}$ ) analysis (PHILIPS diffractometer with $\mathrm{CuK} \alpha$-radiation, $\mathrm{K}$-alpha1 $=1.54060$ $\left.\left[{ }^{\circ} \mathrm{A}\right]\right)$ was used for phase identification. Therefore, bars of the three compositions were crushed and milled to achieve a maximum grain size of $20 \mu \mathrm{m}$.

The corrosion resistance of the different compositions against molten steel and slag were determined in a laboratory melting device (metal casting simulator, SYSTEC, Karlstadt, Germany), the structure und functionality of which have been described by Dudczig et al. [16]. The samples were fixed to an equipment and attached to a crucible (Figure 1). Afterwards, the crucible was filled with approximately $30 \mathrm{~kg}$ of steel grade $18 \mathrm{CrNiMo} 7-6$ (Deutsche Edelstahlwerke $\mathrm{GmbH}$, Witten, Germany).

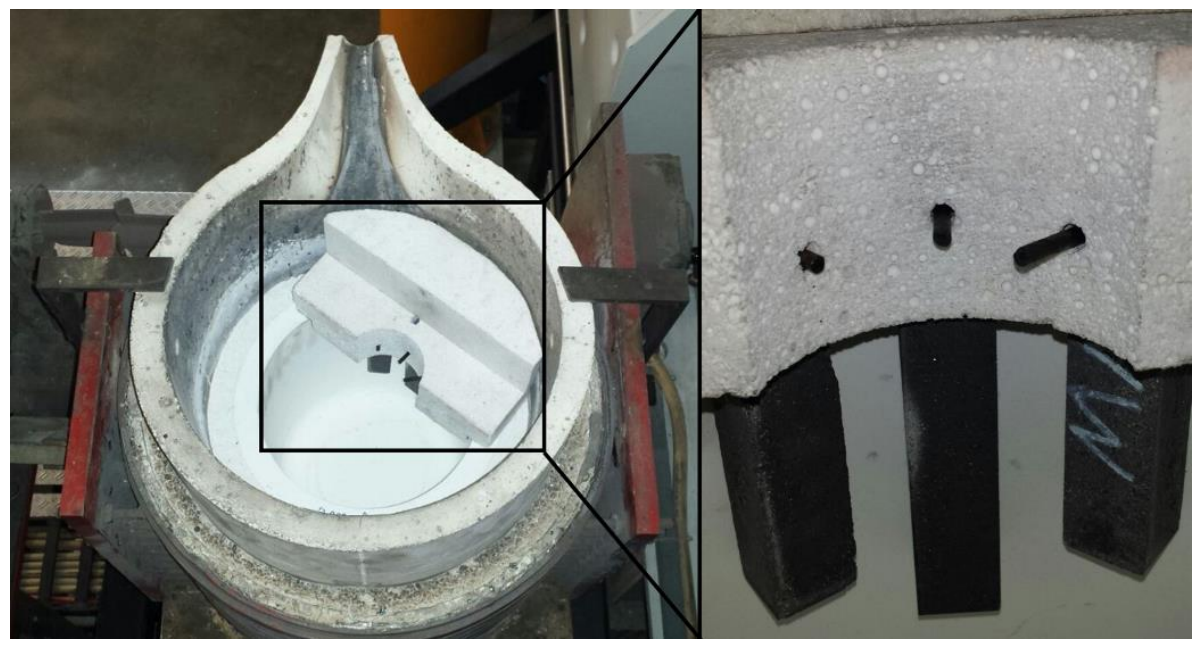

Figure 1. Equipment for corrosion test of samples.

A basic slag was synthesized as corrosion medium by mixing 19 wt.\% Ciment Fondu, $52 \mathrm{wt} . \%$ LDSF RG, 6 wt.\% CMA 72 (all Imerys Aluminates, Paris La Defense, France), 3 wt.\% MS 971 (ELKEM AS, Oslo, Norway), 3.5 wt. \% nedMag 99 (Nedmag B.V., Veendam, The Netherlands), and 30.5 wt. $\% \mathrm{CaCO}_{3}$ (Carl Roth GmbH, Karlsruhe, Germany). Table 3 lists the chemical composition of the synthesized slag (analyzed by X-ray fluorescence analysis). After mixing, the slag was granulated, calcined at $1000^{\circ} \mathrm{C}$, 
and sieved to grain size in the range of $100-500 \mu \mathrm{m}$. This will prevent dust formation during addition to the steel melt as well as prevent degassing reactions during the test run. The steel was melted at approximately $1580^{\circ} \mathrm{C}$ under a fully controlled argon atmosphere. Afterwards, the slag was stepwise added to the top of the steel melt via a feed unit. Investigations in a hot stage microscope in air revealed a melting temperature (hemisphere temperature) of the synthetic slag of $1304{ }^{\circ} \mathrm{C}$. Due to metal melt flow caused by induction field heating, the slag melts and first accumulates at the sidewall of the crucible, where the samples are located. After adding more slag, the whole steel melt gets covered by the synthetic slag having a thickness of 5 to $10 \mathrm{~mm}$ (see Figure 2). These conditions were kept constant for $30 \mathrm{~min}$, followed by shutting down the metal casting simulator.

Table 3. Chemical composition of the synthesized ladle slag.

\begin{tabular}{cc}
\hline Compound & Synthetic Slag (wt.\%) \\
\hline $\mathrm{Al}_{2} \mathrm{O}_{3}$ & 42.4 \\
$\mathrm{CaO}$ & 40.0 \\
$\mathrm{SiO}$ & 6.0 \\
$\mathrm{MgO}$ & 8.3 \\
$\mathrm{Fe}_{2} \mathrm{O}_{3}$ & 0.1 \\
$\mathrm{TiO}_{2}$ & 0.9 \\
$\mathrm{P}_{2} \mathrm{O}_{5}$ & 0.002 \\
$\mathrm{~S}$ & 0.07 \\
$\mathrm{Traces}$ & 2.228 \\
\hline
\end{tabular}

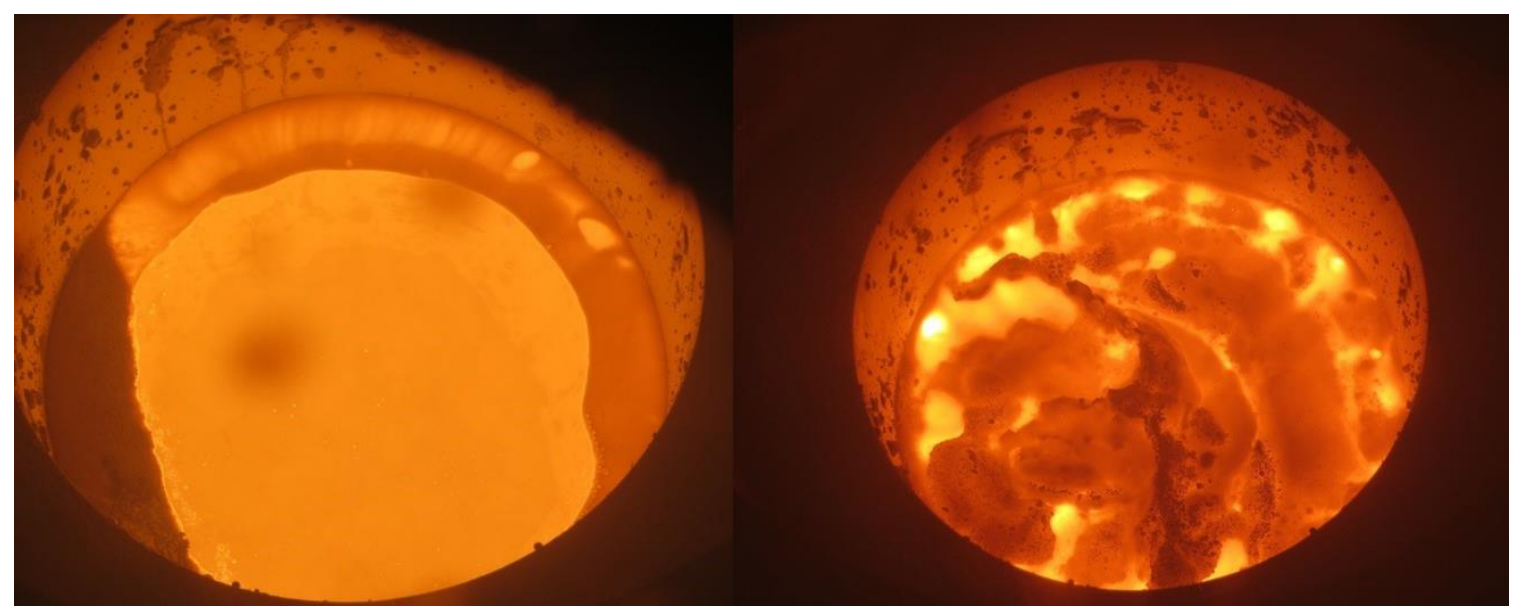

Figure 2. Formation of slag layer on top of molten steel in the crucible inside the metal casting simulator (exemplary without sample equipment).

After laboratory testing, the corrosion was evaluated at a macroscopic scale, with aid of digital light microscopy and with SEM/EDS (scanning electron microscope with energy dispersive spectroscopy) (ESEM XL30 FEG, FEI, Eindhoven, The Netherlands).

\section{Results and Discussion}

\subsection{Phase Composition-XRD}

Since the CA-phases containing in spinel-binder CMA 72 are able to interact with $\mathrm{MgO}$ in a different way compared to AR78 (slight alumina-excess, see Table 1), it is expected that thermal treatment will lead to different phases depending on the added spinel raw material [17]. The spinel portion of CMA 72 is almost stoichiometric, and it is not expected that they will interact with the other constituents of the sample body during carbonization. But the CA-phases $\left(C A\right.$ and $\left.\mathrm{CA}_{2}\right)$ may react 
with $\mathrm{MgO}$ forming additional spinel if the carbonization temperature is high enough. In contrast, AR78 contains free alumina and may react with $\mathrm{MgO}$ to form spinel, even at a lower temperature.

Table 4 lists all main and trace phases of sample $\mathrm{MgO}-\mathrm{C}, \mathrm{M}-\mathrm{AR}-\mathrm{C}$, and M-CMA-C after carbonization at $1400{ }^{\circ} \mathrm{C}$. The $\mathrm{MgO}-\mathrm{C}$ reference sample contains $\mathrm{MgO}$ and carbon, and $\mathrm{Ca}_{3} \mathrm{Mg}\left(\mathrm{SiO}_{4}\right)_{2}$ as a trace phase, which is contained in the $\mathrm{MgO}$ raw material as a well-known impurity. Sample M-AR-C consist of $\mathrm{MgO}, \mathrm{MgAl}_{2} \mathrm{O}_{4}, \mathrm{C}$, and the trace phase $\mathrm{Ca}_{3} \mathrm{Mg}\left(\mathrm{SiO}_{4}\right)_{2}$. By comparing the peak positions (main spinel peak) of sample M-AR-C and the raw material AR78, a slight shift from $31.35^{\circ} 2$ Theta (AR78) to $31.45^{\circ} 2$ Theta can be observed in the diffractogram (see Figure 3). This is an indication that AR78 incorporates some trace elements into the structure. In sample M-CMA-C, MgO, C, and $\mathrm{MgAl}_{2} \mathrm{O}_{4}$, but no CA-phases (e.g., $\mathrm{CaAl}_{2} \mathrm{O}_{4}$ ) can be detected. The absence of CA-phases indicates that (a) an additional spinel formation by reaction of $\mathrm{MgO}$ with $\mathrm{Al}_{2} \mathrm{O}_{3}$ of the CA-phases of the CMA raw material may take place, (b) the contained amount of CA-phases is below the detection limit of $1 \mathrm{wt} . \%$, or (c) a glassy phase was formed by reaction of CA-phases with calcium silicate impurities in $\mathrm{MgO}$. The detectable additional spinel formation by XRD method (peak high and width) is only marginal. Overall, a higher spinel peak can be detected in sample M-CMA-C compared to sample M-AR-C, as well as a peak shift from 31.3 to $31.45^{\circ} 2$ Theta). Of course, based on the information given by XRD-diffractogram the total spinel content cannot be calculated.

Table 4. Main and trace phases after carbonization at $1400^{\circ} \mathrm{C}$.

\begin{tabular}{ccc}
\hline Sample & Main Phase & Traces \\
\hline $\mathrm{MgO}-\mathrm{C}$ & $\mathrm{MgO}, \mathrm{C}$ & $\mathrm{Ca}_{3} \mathrm{Mg}\left(\mathrm{SiO}_{4}\right)_{2}$ \\
$\mathrm{M}-\mathrm{AR}-\mathrm{C}$ & $\mathrm{MgO}^{\mathrm{MgAl}} \mathrm{O}_{4}, \mathrm{C}$ & $\mathrm{Ca}_{3} \mathrm{Mg}\left(\mathrm{SiO}_{4}\right)_{2}$ \\
$\mathrm{M}-\mathrm{CMA}-\mathrm{C}$ & $\mathrm{MgO}, \mathrm{MgAl}_{2} \mathrm{O}_{4}, \mathrm{C}$ & - \\
\hline
\end{tabular}

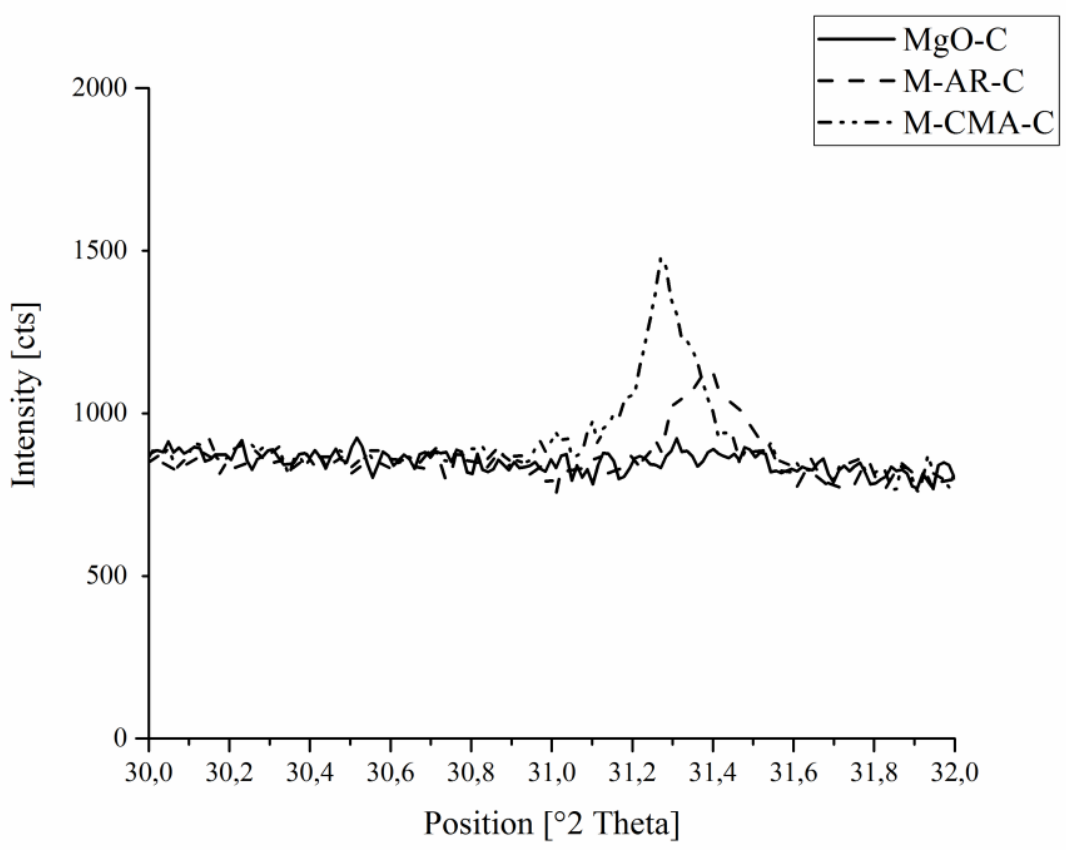

Figure 3. XRD spectra variation in the vicinity of $\mathrm{MgAl}_{2} \mathrm{O}_{4}$ peak structure in sample $\mathrm{MgO}-\mathrm{C}, \mathrm{M}-\mathrm{AR}-\mathrm{C}$, and M-CMA-C (extraction of diffractogram).

\subsection{Laboratory Metal Casting Simulator Test}

The slag and molten steel could not be poured into the tundish after the test run, as the samples were fixed to the crucible. Consequently, after shutting down the induction heating, the samples effectively froze in the steel and slag, but slag and steel could easily be separated. Hence, broken sample bits with contact to steel melt and slag are existent to perform investigations. Above the slag 
line, all three sample bars show a decarburization area. At the macroscopic scale, no specific differences are detectable. The edges are not sharp anymore, but no particular washout can be noticed. Light microscopy investigations on polished surfaces of the samples at 50-times magnification revealed much more differences in corrosion behavior (Figure 4). Compared to sample M-CMA-C and M-AR-C, the interface of sample $\mathrm{MgO}-\mathrm{C}$ is irregular and presents numerous exposed grains. It is not possible to calculate the total slag infiltration depth as the initial sample edge cannot be discerned. But taking the highest and lowest part of the slag-refractory interface into account, an infiltration depth above 1.2 $\mathrm{mm}$ was calculated at sample MgO-C. The slag-refractory interface of sample M-AR-C with coarse AR78 has a wavy character, which indicates a washout of coarse and fine parts of the material. The slag infiltration depth was calculated being in the range of $800 \mu \mathrm{m}$. In contrast, the sample containing CMA 72 (M-CMA-C) shows a clear slag-refractory interface with average slag infiltration depth in a range of 100-200 $\mu \mathrm{m}$, which indicates less interaction of the refractory material with slag.

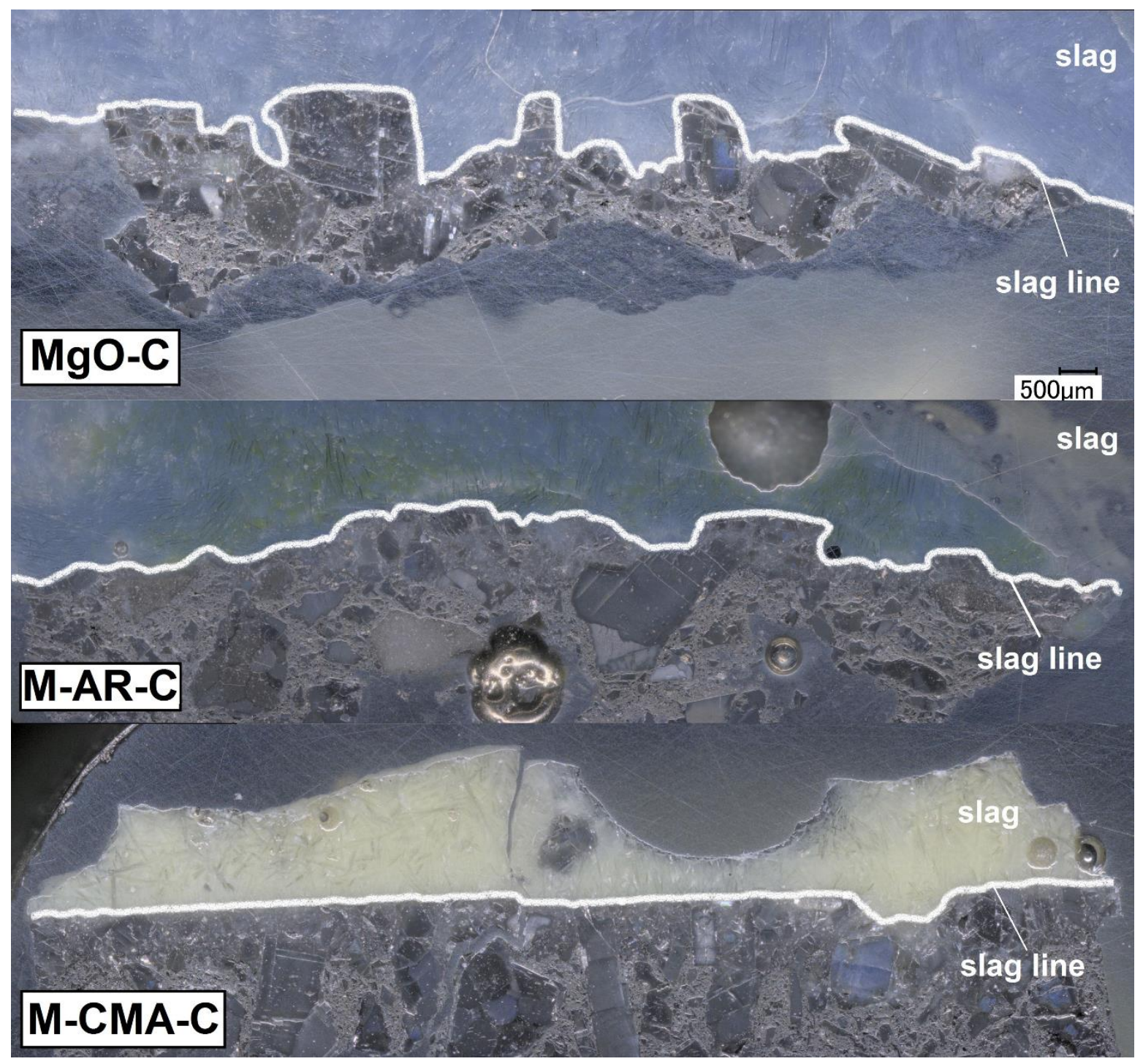

Figure 4. Polished slag-refractory interface after corrosion test.

Figure 5a displays the slag-refractory interface of reference sample $\mathrm{MgO}-\mathrm{C}$ analyzed with SEM. It is obvious that the slag easily attacks the $\mathrm{MgO}$ coarse grains and matrix particles after the graphite and the carbon binder components were oxidized. The fine matrix particles were surrounded and dissolved by slag at an early stage of corrosion test. The coarse grains were infiltrated by slag as 
well, which will cause a stepwise decomposition. Figure $5 \mathrm{~b}$ presents an interspace between coarse $\mathrm{MgO}$ grains filled with slag located approx. $200 \mu \mathrm{m}$ beyond the slag line. There are three different compositions detectable, which were analyzed by EDS. An overview of the composition at all EDS spots is given in Table 5. The main grey area contains $45 \mathrm{wt} . \% \mathrm{Al}_{2} \mathrm{O}_{3}, 30 \mathrm{wt} . \% \mathrm{CaO}, 20 \mathrm{wt} . \% \mathrm{SiO}_{2}$, and 5 wt. $\% \mathrm{MgO}$ (spot 1). According to the $\mathrm{Al}_{2} \mathrm{O}_{3}-\mathrm{CaO}-\mathrm{MgO}-\mathrm{SiO}_{2}$ quaternary system with $5 \mathrm{wt} . \%$ $\mathrm{MgO}$, the detected composition at spot 1 lies in the field of stability of spinel and nearby melilite (more precise akermanite) phase [18]. The grey area at spot 2 consists of about $38 \mathrm{wt} . \% \mathrm{Al}_{2} \mathrm{O}_{3}, 15 \mathrm{wt} . \% \mathrm{SiO}_{2}$, $7 \mathrm{wt} . \% \mathrm{MgO}, 3 \mathrm{wt} . \%$ of sulphur-containing phase, and shows a depletion of $\mathrm{CaO}$. This composition lies on the liquidus line of spinel and melilite $\left(\mathrm{Ca}_{2} \mathrm{MgSi}_{2} \mathrm{O}_{7}\right)$. In comparison to spot 2, the light grey spot 3 shows a low silica content and high amounts of $\mathrm{TiO}_{2}$ and sulphur. Compared to initial synthetic slag composition (Table 3), an increase of silica and alumina, as well as depletion of $\mathrm{CaO}$, can be detected in the slag between the $\mathrm{MgO}$ grains. The discrepancy of the composition of detected EDS-spots in comparison to synthetic slag implies the interaction of $\mathrm{MgO}-\mathrm{C}$ reference material and its impurities especially with $\mathrm{CaO}$ of the slag. However, according to the $\mathrm{MgO}-\mathrm{CaO}$ binary system, in range of 1600 ${ }^{\circ} \mathrm{C} \mathrm{MgO}$ will not be dissolved by $\mathrm{CaO}$ but forms a solid solution. This was also proven by higher $\mathrm{CaO}$ content nearby slag-refractory interface compared to $\mathrm{CaO}$ content detected in slag far away from $\mathrm{MgO}-\mathrm{C}$ material. The interaction of $\mathrm{MgO}-\mathrm{C}$ with $\mathrm{CaO}$ or calcium silicates results in a eutectic slag with lower melting point and lower viscosity, which will easily penetrate the $\mathrm{MgO}-\mathrm{C}$ reference material. $\mathrm{Al}_{2} \mathrm{O}_{3}$ and sulphur (originating from slag) seem to play only a minor role on the corrosion, and $\mathrm{TiO}_{2}$ does not take part in the corrosion reaction. Furthermore, spinel, melilite, or anorthite are able to crystallize in the slag during cooling.

Figure $5 c$ displays the slag-refractory interface of sample M-AR-C composed of a mixture of coarse grains and numerous fine particles surrounded by slag. Similar to sample $\mathrm{MgO}-\mathrm{C}$, slag with three different compositions is detectable inside the coarse grains of sample M-AR-C (Figure $5 \mathrm{~d}$ ). The dominating dark grey area (spot 4) consists of about $40 \mathrm{wt} . \% \mathrm{Al}_{2} \mathrm{O}_{3}, 30 \mathrm{wt} . \% \mathrm{CaO}, 20 \mathrm{wt} . \% \mathrm{SiO}_{2}, 5$ wt.\% $\mathrm{MgO}$, and some sulphur. Like spot 2, these composition lies on the liquidus line of melilite and spinel. Composition at spot 5 is rich in $\mathrm{CaO}(50 \mathrm{wt} . \%)$ and $\mathrm{SiO}_{2}(35 \mathrm{wt} . \%)$ and has a very low amount of $\mathrm{Al}_{2} \mathrm{O}_{3}$ ( $\left.5 \mathrm{wt} . \%\right), \mathrm{MgO}(2 \mathrm{wt} . \%), \mathrm{TiO}_{2}$, and sulphur. Light grey spot 6 correlates to a Ca- and S-rich phase. Compared to initial synthetic slag, $\mathrm{CaO}$ content is nearly constant, there is an increase in $\mathrm{SiO}_{2}$ content and a depletion of $\mathrm{Al}_{2} \mathrm{O}_{3}$. Hence, in contrast to sample $\mathrm{MgO}-\mathrm{C}$, sample $\mathrm{M}-\mathrm{AR}-\mathrm{C}$ will react with $\mathrm{CaO}$ and additionally with $\mathrm{Al}_{2} \mathrm{O}_{3}$, which will intensify the basicity of the residual slag which results in higher melting point and hence higher viscosity, and consequently less slag penetration. EDS investigations of the slag far away from M-AR-C material interphase verify these findings, as lower $\mathrm{Al}_{2} \mathrm{O}_{3}$ content but higher $\mathrm{CaO}$ content was detected compared to slag far away from sample MgO-C. The slag inside sample M-AR-C has the potential of crystallization of rankinite as well as anorthite and CA. In addition, there is a crystallization of $\mathrm{CaS}$.

Figure $5 \mathrm{e}, \mathrm{f}$ displays two slag-refractory interfaces of sample M-CMA-C. Two different zones can be detected: (a) an infiltration zone with coarse and fine particles surrounded by slag, and (b) the initial refractory material. Infiltration and dissolution take place but less of the solved material will be transported into the slag compared to sample M-AR-C. The infiltration zone (spot 8) is composed of 48 wt. $\% \mathrm{Al}_{2} \mathrm{O}_{3}, 37 \mathrm{wt} . \% \mathrm{CaO}, 10 \mathrm{wt} . \% \mathrm{SiO}_{2}$, and $4 \mathrm{wt} . \% \mathrm{MgO}$, which can be assigned to the spinel stability field. Sample M-CMA-C will additionally react with $\mathrm{Al}_{2} \mathrm{O}_{3}$, which will result in a higher melting point, higher viscosity, and reduced slag penetration. EDS investigations of the slag far away from sample M-CMA-C revealed nearly similar composition like those of sample M-AR-C. The residual penetrating slag inside one of the bigger grains is composed of $32.5 \mathrm{wt} . \% \mathrm{MgO}, 43 \mathrm{wt} . \% \mathrm{SiO}_{2}$, and $24.5 \mathrm{wt} . \% \mathrm{CaO}$ (EDS spot 7). This composition lies next to the field of stability of $\mathrm{MgO}$. By interaction with $\mathrm{MgO}$, forsterite $\left(\mathrm{M}_{2} \mathrm{~S}\right)$ or monticellite (CMS) will be formed until the stability field of $\mathrm{MgO}$ will be reached very fast. This will disrupt further corrosion. 


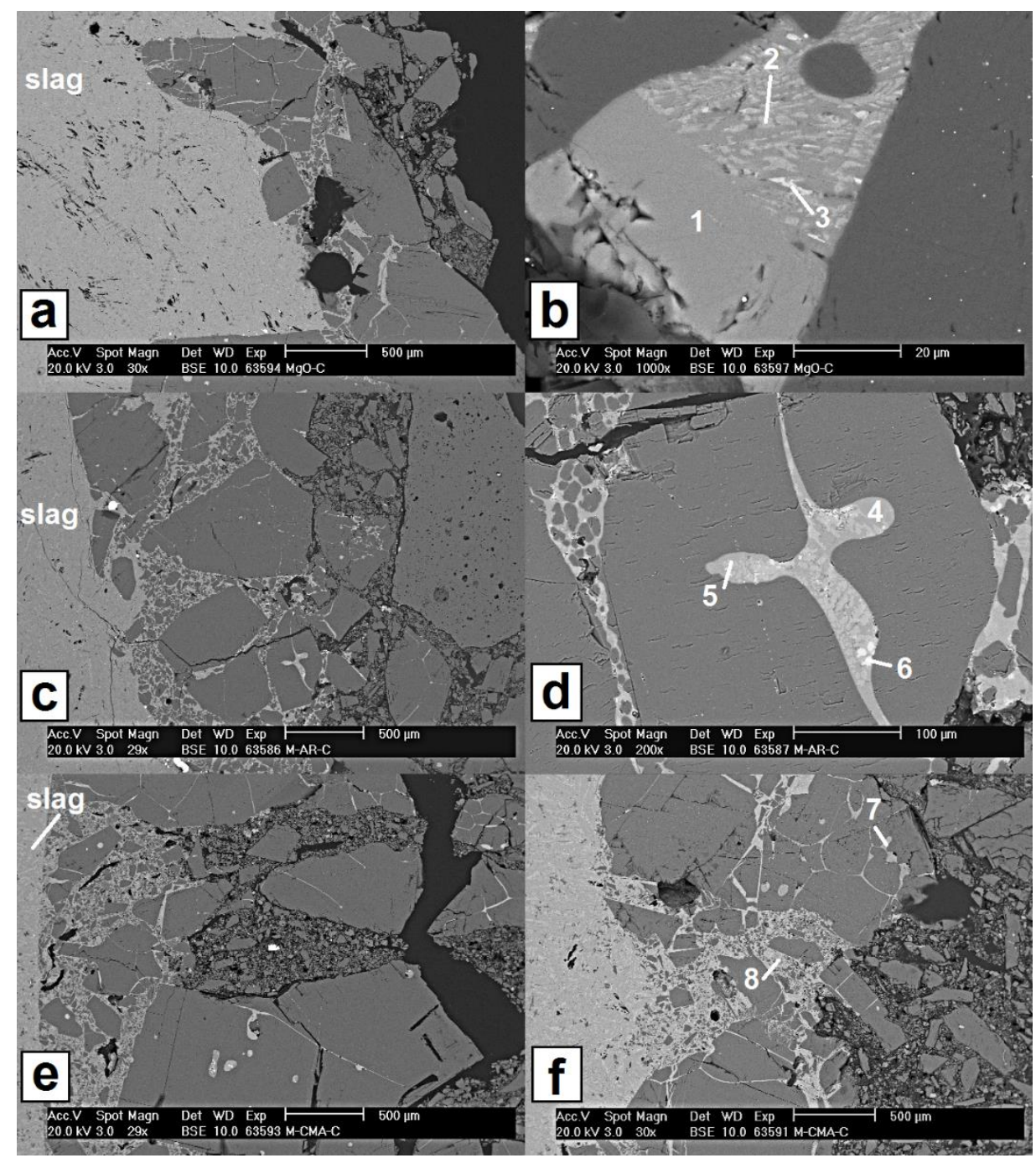

Figure 5. Slag-refractory interface of sample $\mathrm{MgO}-\mathrm{C}$ at 30× magnification (a), space between grains filled with slag at 1000-times magnification (b), interface of sample M-AR-C at 30-times magnification (c) and grain filled with slag at 200× magnification (d), and slag-refractory interfaces of sample M-CMA-C at 30-times magnification (e,f) including marks of EDS spot analysis.

Table 5. Results of EDS spot analysis in SEM.

\begin{tabular}{ccccccc}
\hline \multirow{2}{*}{ Spot } & \multicolumn{7}{c}{ Compound (wt.\%) } \\
\cline { 2 - 7 } & $\mathbf{A l}_{\mathbf{2}} \mathbf{O}_{\mathbf{3}}$ & $\mathbf{M g O}$ & $\mathbf{S i O}_{\mathbf{2}}$ & $\mathbf{C a O}$ & $\mathbf{T i O}_{2}$ & $\mathbf{S O}_{3}$ \\
\hline 1 & 46.3 & 4.7 & 18.9 & 29.9 & 0.3 & - \\
2 & 37.6 & 7.2 & 15.5 & 35.4 & 1.0 & 3.3 \\
3 & 39.9 & 3.8 & 5.2 & 34.0 & 8.0 & 9.1 \\
4 & 40.2 & 4.5 & 22.6 & 30.1 & - & 2.6 \\
5 & 4.9 & 1.8 & 33.8 & 52.7 & 1.0 & 5.9 \\
6 & - & - & - & 36.7 & - & 63.3 \\
7 & - & 32.5 & 43.1 & 24.4 & - & - \\
8 & 47.5 & 3.6 & 10.4 & 37.2 & 1.3 & - \\
\hline
\end{tabular}

\section{Conclusions}

The aim of this work was to identify the influence of AR78 and CMA 72 on the corrosion mechanism of MgO-C, determined by a laboratory corrosion test in a metal casting simulator with 
steel $18 \mathrm{CrNiMo} 7-6$ and synthetic slag at $1580{ }^{\circ} \mathrm{C}$ for $30 \mathrm{~min}$. The reference sample $\mathrm{MgO}-\mathrm{C}$ without spinel addition gets infiltrated by slag and shows intense dissolving especially by $\mathrm{CaO}$. The slag resulting from this reaction still has a highly reactive character, which explains the high corrosion rate. $\mathrm{MgO}-\mathrm{C}$ containing alumina-rich spinel $\mathrm{AR78}$ also reacts with $\mathrm{CaO}$ but additionally with $\mathrm{Al}_{2} \mathrm{O}_{3}$ from the slag. This leads to a depletion of $\mathrm{Al}_{2} \mathrm{O}_{3}$ in the infiltrated slag, increases its basic character, and consequently reduces its reactivity (stability field of melilite and spinel), observable in reduced corrosion compared to reference $\mathrm{MgO}-\mathrm{C}$. The $\mathrm{MgO}-\mathrm{C}$ sample containing CMA 72 also reacts with $\mathrm{CaO}$ and $\mathrm{Al}_{2} \mathrm{O}_{3}$ of the infiltrated slag, but the resulting slag composition lies in the stability field of spinel and next to $\mathrm{MgO}$. Consequently, by further reaction with the infiltrated slag, the formation of forsterite $\left(\mathrm{M}_{2} \mathrm{~S}\right)$ or monticellite (CMS) is expected until the stability field of $\mathrm{MgO}$ will be reached very fast. This will disrupt further corrosion and explains the very low corrosion rate.

Author Contributions: Conceptualization, P.G., C.W. and C.P.; Investigation, P.G., S.D. and G.S.; Project administration, C.P. and C.G.A.; Supervision, C.G.A.; Writing-original draft, P.G.; Writing-review \& editing, P.G., S.D., G.S., C.W., C.P. and C.G.A. All authors have read and agreed to the published version of the manuscript.

Funding: This research received no external funding.

Acknowledgments: The authors are grateful to Marcus Schreiner for XFA analysis of synthetic slag.

Conflicts of Interest: The authors declare no conflict of interest.

\section{References}

1. Figueiredo, A., Jr.; Bellandi, N.; Vanola, A.; Zambohi, L. Technological evolution of magnesia-carbon bricks for steel ladles in Argentina. Iron Steel Technol. 2004, 1, 42-47.

2. Lee, W.E.; Zhang, S. Melt corrosion of oxide and oxide-carbon refractories. Int. Mater. Rev. 1999, 44, 77-104. [CrossRef]

3. Tripathi, H.S.; Ghosh, A. Spinelisation and properties of $\mathrm{Al}_{2} \mathrm{O}_{3}-\mathrm{MgAl}_{2} \mathrm{O}_{4}-\mathrm{C}$ refractory: Effect of $\mathrm{MgO}$ and $\mathrm{Al}_{2} \mathrm{O}_{3}$ reactants. Ceram. Int. 2010, 36, 1189-1192. [CrossRef]

4. Nourbakhsh, A.A.; Salarian, S.; Hejazi, S.M.; Shojaiei, S.; Golestani-Fard, F. Increasing durability of ladle lining refractories by utilizing $\mathrm{Al}_{2} \mathrm{O}_{3}-\mathrm{MgO}-\mathrm{C}$ bricks. In Proceedings of the UNITECR'03: 8th Biennial Worldwide Conference on Refractories, Osaka, Japan, 19-22 October 2003.

5. Musante, L.; Muñoz, V.; Labadie, M.H.; Tomba Martinez, A.G. High temperature mechanical behavior of $\mathrm{Al}_{2} \mathrm{O}_{3}-\mathrm{MgO}-\mathrm{C}$ refractories for steelmaking use. Ceram. Int. 2011, 37, 1473-1483. [CrossRef]

6. Gehre, P.; Aneziris, C.G.; Berek, H.; Parr, C.; Reinmöller, M. Corrosion of magnesium aluminate spinel-rich refractories by sulphur-containing slag. J. Eur. Ceram. Soc. 2015, 35, 1613-1620. [CrossRef]

7. Ghasemi-Kahrizsangi, S.; Gheisari Dehsheikh, H.; Boroujerdnia, M. Effect of micro and nano- $\mathrm{Al}_{2} \mathrm{O}_{3}$ addition on the microstructure and properties of MgO-C refractory ceramic composite. Mater. Chem. Phys. 2017, 189, 230-236. [CrossRef]

8. Choi, T.H.; Jun, B.S. Wear mechanism of $\mathrm{MgO}-\mathrm{C}$ refractory with thermite reaction products of $\mathrm{MgO}$ and $\mathrm{Al}$. J. Korean Ceram. Soc. 1996, 33, 830-832.

9. Xue, J. Development and application of ultra-low-carbon-containing $\mathrm{MgO}-\mathrm{MgAl}_{2} \mathrm{O}_{4}-\mathrm{C}$ bricks for ladle slag line. Naihuo Cailiao/Refractories 2011, 45, 107-109.

10. Ganesh, I.; Bhattacharjee, S.; Saha, B.P.; Johnson, R.; Rajeshwari, K.; Sengupta, R.; Ramana Rao, M.V.; Mahajan, Y.R. An efficient $\mathrm{MgAl}_{2} \mathrm{O}_{4}$ spinel additive for improved slag erosion and penetration resistance of high- $\mathrm{Al}_{2} \mathrm{O}_{3}$ and $\mathrm{MgO}-\mathrm{C}$ refractories. Ceram. Int. 2002, 28, 245-253. [CrossRef]

11. Das, R.R.; Nayak, B.B.; Adak, S.; Chattopadhyay, A.K. Influence of nanocrystalline $\mathrm{MgAl}_{2} \mathrm{O}_{4}$ spinel addition on the properties of MgO-C refractories. Mater. Manuf. Process. 2012, 27, 242-246. [CrossRef]

12. Wu, J.; Gu, H.; Zhao, J.; Huang, A.; Liu, L. Effect of $\mathrm{CaAl}_{4} \mathrm{O}_{7}-\mathrm{MgAl}_{2} \mathrm{O}_{4}$ on thermal shock resistance of low-carbon MgO-C brick. Naihuo Cailiao/Refractories 2012, 46, 440-442.

13. Aneziris, C.G.; Gehre, P. Effects of magnesium aluminate spinel raw materials on the material properties of $\mathrm{MgO}-\mathrm{C}$ refractories. In Proceedings of the 59th International Colloquium on Refractories, Aachen, Germany, 28-29 September 2016; Volume 59, pp. 242-245.

14. Gehre, P.; Wöhrmeyer, C.; Aneziris, C.G.; Parr, C.; Parr, C. Functional spinel-binder based additives for improved MgO-C performance in ladle applications. Refract. Worldforum 2017, 9, 83-88. 
15. Pagliosa, C.; Souza, P.V.; Hama, N.; Wöhrmeyer, C.; Zetterström, C.; Evangelista, P.C. Improvement of MAC bricks for steel ladle with $\mathrm{CaO}-\mathrm{MgO}-\mathrm{Al}_{2} \mathrm{O}_{3}$ aggregate: A new perspective for cement application. In Proceedings of the Proceeding O046, UNITECR 2017-15th Biennial Worldwide Congress, Santiago, Chile, 26-29 September 2017; pp. 169-172.

16. Dudczig, S.; Aneziris, C.G.; Emmel, M.; Schmidt, G.; Hubalkova, J.; Berek, H. Characterization of carbon-bonded alumina filters with active or reactive coatings in a steel casting simulator. Ceram. Int. 2014, 40, 16727-16742. [CrossRef]

17. Wöhrmeyer, C.; Parr, C.; Fryda, H.; Auvray, J.-M.; Touzo, B.; Guichard, S. New spinel containing calcium aluminate cement for corrosion resistant castables. In Proceedings of the 12th Biennial Worldwide Conference on Refractories, Kyoto, Japan, 30 October-2 November 2011.

18. Allibert, M.; Gaye, H.; Geisler, J.; Janke, D.; Keene, B.J.; Kirner, D.; Kowalski, M.; Lehmann, J.; Mills, K.C.; Neuschutz, D.; et al. Slag Atlas; Verl. Stahleisen: Düsseldorf, Germany, 1995; ISBN 3-514-00457-9.

(C) 2020 by the authors. Licensee MDPI, Basel, Switzerland. This article is an open access article distributed under the terms and conditions of the Creative Commons Attribution (CC BY) license (http://creativecommons.org/licenses/by/4.0/). 